NBER WORKING PAPER SERIES

\title{
SUSTAINABILITY AND THE MEASUREMENT OF WEALTH
}

\author{
Kenneth J. Arrow \\ Partha Dasgupta \\ Lawrence H. Goulder \\ Kevin J. Mumford \\ Kirsten Oleson \\ Working Paper 16599 \\ http://www.nber.org/papers/w16599
}

\author{
NATIONAL BUREAU OF ECONOMIC RESEARCH \\ 1050 Massachusetts Avenue \\ Cambridge, MA 02138 \\ December 2010
}

We are most grateful to Kirk Hamilton and his colleagues at the World Bank for very helpful comments and making their data available to us. The views expressed herein are those of the authors and do not necessarily reflect the views of the National Bureau of Economic Research.

NBER working papers are circulated for discussion and comment purposes. They have not been peerreviewed or been subject to the review by the NBER Board of Directors that accompanies official NBER publications.

(C) 2010 by Kenneth J. Arrow, Partha Dasgupta, Lawrence H. Goulder, Kevin J. Mumford, and Kirsten Oleson. All rights reserved. Short sections of text, not to exceed two paragraphs, may be quoted without explicit permission provided that full credit, including $(\subset$ notice, is given to the source. 
Sustainability and the Measurement of Wealth

Kenneth J. Arrow, Partha Dasgupta, Lawrence H. Goulder, Kevin J. Mumford, and Kirsten

Oleson

NBER Working Paper No. 16599

December 2010

JEL No. D69,O10,O47,O50,Q32,Q39

\begin{abstract}
$\underline{\text { ABSTRACT }}$
We develop a consistent and comprehensive theoretical framework for assessing whether economic growth is compatible with sustaining well-being over time. The framework focuses on whether a comprehensive measure of wealth - one that accounts for natural capital and human capital as well as reproducible capital - is maintained through time. Our framework also integrates population growth, technological change, and changes in health. We apply the framework to five countries that differ significantly in stages of development and resource bases: the United States, China, Brazil, India, and Venezuela. With the exception of Venezuela, significant increases in human capital enable comprehensive wealth to be maintained (and sustainability to be achieved) despite significant reductions in the natural resource base. We find that the value of "health capital" is very large relative to other forms of capital. As a result, its growth rate critically influences the growth rate of per-capita comprehensive wealth.
\end{abstract}

Kenneth J. Arrow

Stanford University

arrow@stanford.edu

Partha Dasgupta

Faculty of Economics \& Politics

University of Cambridge

The Austin Robinson Building

Cambridge, ENGLAND CB3 9DD

partha.dasgupta@econ.cam.ac.uk

Lawrence H. Goulder

Department of Economics

Landau Economics Building 328

Stanford University

Stanford, CA 94305

and NBER

goulder@stanford.edu
Kevin J. Mumford

Department of Economics

Purdue University

100 S Grant St

West Lafayette, IN 47907

mumford@purdue.edu

Kirsten Oleson

Public Policy Program

Stanford University

Stanford, CA 94305

koleson@stanford.edu 


\section{Introduction}

The last two decades have witnessed growing concern that the pattern of economic growth in many countries is not sustainable because of the depletion in stocks of many natural resources and the deterioration in the quality of various environmental services. These concerns have helped spawn a growing literature on "sustainable development." This emerging literature expands traditional growth-accounting approaches by giving considerable attention to natural resource stocks and environmental quality.

This paper aims to advance this literature. We extend earlier work by offering a fully consistent theoretical framework that offers a clear criterion for sustainable development. This framework yields an empirically implementable measure of whether a given national economy is following a sustainable path. We apply this framework to five countries that differ significantly in terms of their stages of development and resource bases: the United States, China, Brazil, India, and Venezuela.

\subsection{What Should Be Sustained if Development Is to Be Sustainable?}

As sustainable development must refer to a path of development that sustains (prevents the diminishing of) something, our first requirement is to state what that "something" should be. In a landmark report, the Brundtland Commission (World Commission, 1987: p.70) defined sustainable development as "... development that meets the needs of the present without compromising the ability of future generations to meet their own needs."

Note that the definition makes no mention of human well-being. Relatedly, it makes relatively weak demands on intergenerational justice. In the Commission's view, sustainable development requires that future generations have no less of the means to meet their needs than we do currently; it requires nothing more. As needs are the austere component of well-being, economic development could be sustainable in the Commission's sense without having much to show for it.

Note also that the Commission's definition is directed at sustaining the factors that go to meet needs. In their view "sustainable development" requires that relative to their populations each generation should bequeath to its successor at least as large a quantity of what may be 
called an economy's "productive base" as it had itself inherited from its predecessor. That raises another problem with the Commission's reasoning: it does not explain how the productive base should be measured.

We take the view that economic development should be evaluated in terms of its contribution to intergenerational well-being. Specifically, we identify sustainable development with economic paths along which intergenerational well-being does not decline. In view of what is already known about the relationship between real national income and social well-being in a timeless economy (e.g., Samuelson, 1961), we should expect that there is a measure of an economy's productive base that reflects intergenerational well-being. We show below that intergenerational well-being would not decline over a specified time-period if and only if a comprehensive measure of the economy's wealth were not to decline over the same period. By wealth we mean the social worth of an economy's entire productive base. Because the productive base consists of the entire range of factors that determine intergenerational wellbeing, we will sometimes refer to wealth as comprehensive wealth. ${ }^{1}$

What are the raw ingredients of wealth? It is intuitive that an economy's productive base comprises the entire range of capital assets to which people have access. Wealth therefore includes not only reproducible capital goods (roads, buildings, machinery and equipments), human capital (health, education, skills), and natural capital (ecosystems, minerals and fossil fuels); but also population (size and demographic profile), public knowledge, and the myriad of formal and informal institutions that influence the allocation of resources. We will see presently that reproducible capital, human capital, and natural capital enter quantitative estimates of sustainable development in a somewhat different way from population, public knowledge, and institutions.

With a complete set of competitive markets, it would be relatively straightforward to calculate wealth. One could observe the prices of assets as they are traded, or alternatively consider the present value of the flow of income generated by the assets, as revealed through forward markets. In the world as we know it, though, many of the productive assets and the goods and services they generate (e.g. public goods, human capital, institutions) are not traded; in addition, forward markets often do not exist for the associated income flows. Calculating the

\footnotetext{
${ }^{1}$ Recent efforts to arrive at more broad-based national income accounts express a similar spirit to the present study in showing an appreciation for more comprehensive accounting. Important steps for improved national income accounts for the U.S. are provided in Jorgenson, Landefeld, and Nordhaus (2006).
} 
value of human capital, for example, has proved to be exceptionally difficult because there is no direct market for such capital. At least as problematic is the estimation of the health component of human capital (see below) and the shadow value of the stocks of various forms of natural capital (e.g., ecosystems).

\subsection{Wealth and Well-Being}

That movements in wealth should be used to judge the sustainability of development paths was proposed by Pearce and Atkinson (1993), who defined sustainable development to be an economic path along which (comprehensive) wealth does not decline (see also Hamilton, 1994). Although the Pearce-Atkinson definition was not founded on the more basic notion of intergenerational well-being, the paper influenced a bold program of research at the World Bank's Vice Presidency for Environmentally Sustainable Development, where researchers sought to estimate the composition of the wealth of nations and their movements over time (Serageldin and Steer, 1994; Serageldin, 1996; World Bank, 1997).

These publications did not explore the connections between movements in wealth and changes in intergenerational well-being. The connections were identified independently by Hamilton and Clemens (1999) and Dasgupta and Mäler (2000). Assuming a constant population and constant total factor productivity, Hamilton and Clemens showed that at a full optimum intergenerational well-being increases at a date $t$ if and only if comprehensive wealth increases at $t$. Dasgupta and Mäler also assumed constant population, but imposed no restriction on the way economies can be mismanaged; nor did they restrict production possibility sets to be convex.

They showed that even in dysfunctional, non-convex economies intergenerational well-being increases at a date $t$ if and only if comprehensive wealth increases at $t$ (Proposition 1 below). They also uncovered the connection between sustainability analysis and social cost-benefit analysis by showing that even in the latter, wealth is the implicit criterion function.

A change in comprehensive wealth at constant shadow prices is what may be called comprehensive investment. In addition to their theoretical finding, Hamilton and Clemens (1999) extended the empirical work in World Bank (1997) by constructing an improved set of estimates of comprehensive investment (they called it "genuine saving") in 120 countries for the period 1970-1996. To official figures for national saving, the authors added the value of net additions 
to fossil fuels and minerals, forest cover, carbon in the atmosphere, and public expenditure on education. Although comprehensive wealth in a few of the countries in their sample was found to have declined during the period, the authors estimated that it had increased in the vast majority of countries. However, as population had grown in all countries, it was unclear how the Hamilton-Clemens findings on sustainable development were to be interpreted. It may seem self-evident that when population size does not remain constant, wealth per capita tracks intergenerational well-being, but the intuition is unreliable, and in any case requires confirmation by a formal proof. Dasgupta (2001) identified a set of conditions, both on the concept of intergenerational well-being and on technological possibilities, under which per capita wealth tracks intergenerational well-being (Proposition 3 below).

In an important publication, World Bank (2006) extended the empirical findings in Hamilton and Clemens (1999) by estimating changes in (comprehensive) wealth per capita in year 2000 in 120 countries. Obliged as they were to work with so large a sample, limitations in data compelled the authors to ignore changes in a number of potentially important capital assets.

Our aim in this paper is to offer a more complete and consistent theory of the way comprehensive investment should be estimated, and to apply the theory empirically. Our empirical investigation focuses on a small set of countries that differ significantly in terms of their stages of development and resource bases.

\subsection{Plan}

The plan of the paper is as follows. In Section 2 we develop a basic theory and identify the propositions we need. In Section 3 we extend the theory to enable it to embrace technological change and population growth. Section 4 discusses issues relating to the implementation of the theory. In Section 5 we use data for the period 1995-2000 to study whether economic development in a selected number of countries was sustainable. Section 6 concludes and includes discussion of some of the most glaring weaknesses in our empirical work. 


\section{The Basic Model}

We assume a closed economy. Time is continuous and denoted variously by $s$ and $t(s \geq t$ $\geq 0$ ). The horizon is taken to be infinite.

Let $\underline{C}(s)$ denote a vector of consumption flows at time $s$. $\underline{C}(s)$ includes not only marketed consumption goods but also leisure, various health services, and consumption services supplied by nature. Consumption goods are indexed by $j$. Let $\underline{K}(s)$ denote the stocks of a comprehensive list of capital assets at $s$. For simplicity, we assume that demographic changes, movements in total factor productivity, and changes in import and export prices are exogenous. Capital assets are indexed by $i$.

\subsection{A Definition of Sustainability}

To fix ideas, we assume for the moment that population is constant. Let $U(\underline{C}(s))$ be economy-wide felicity (utility flow) at $s$. Denote intergenerational well-being at $t$ by $V(t)$. We assume that

$$
V(t)=\int_{t}^{\infty}\left[U(\underline{C}(s)) e^{-\delta(s-t)}\right] d s, \quad \delta \geq 0 .
$$

where $\delta$ is the felicity discount rate. Thus, intergenerational well-being is the discounted flow of the felicities of current and future generations.

An economic forecast at $t$ is the pair of vector functions $\{\underline{C}(s), \underline{K}(s)\}$ for $s \geq t$. Assume that the integral in expression (1) converges for the forecast. We now state

\section{Definition 1. Economic development is sustained at $t$ if $d V / d t \geq 0$.}

To save on notation, we avoid writing down an explicit dynamical model of the economy. We note that even though the sustainability requirement (condition (2)) is defined at a particular moment in time, the element $V$ requires a forecast of the economy's future beyond $t$. That future depends on the economy's stock of assets at $t$; it also depends on the evolving structure of technology, people's values and preferences, and institutions beyond $t$. The stock of assets at any moment $s$ in the future would be determined by the stocks at the "previous" date. ${ }^{2}$ By

\footnotetext{
${ }^{2}$ We qualify with quotation marks only because in continuous time there is no "previous" date.
} 
proceeding from moment to moment this way, the entire future course of capital stocks would be determined. With a theory of political economy that is reliable enough to track the co-evolution of economic development and the economy's institutions, we could trace institutions at $s$ to capital stocks and the prevailing institutions at $t$. With no reliable theory of political economy available, changes in institutions have to be treated as exogenous events; this is what we do here. Thus, given $\underline{K}(t), \underline{K}(s)$ and $\underline{C}(s)$, and thereby $U(\underline{C}(s))$, are determined for all future times $s \geq t$. Hence from equation (1), $V(t)$ is determined as well. Therefore we can write

$$
V(t)=V(\underline{K}(t), t) .
$$

In equation (3) $V$ depends directly on $t$ to reflect the impact of time-varying factors that we treat as exogenous. These include changes in the terms of trade, technological change, unexplained population growth, and unexplained changes in institutions. By "unexplained" we mean exogenous and thus distinct from the changes that are endogenous to the system. Hence $t$ can be regarded as an additional form of capital asset, an interpretation we will adopt presently. Note that we do not assume the economy to be on an optimum trajectory (see Dasgupta and Mäler, 2000).

\subsection{Shadow Prices}

For simplicity of notation, we take felicity to be the numeraire. Let $q_{j}(t)$ denote the shadow price of consumption good $j$ at time $t$. Then

$$
q_{j}(t)=\partial U(\underline{C}(t)) / \partial C_{j}(t)
$$

We assume that $V(t)$ is differentiable in $\underline{K}^{3}$ Differentiating $V(t)$ with respect to $t$ in (3) and using (2) yields a criterion for sustainable development at $t$ :

$$
d V(t) / d t=\partial V / \partial t+\sum_{i}\left[\left(\partial V(t) / \partial K_{i}(t)\right)\left(d K_{i}(t) / d t\right)\right] \geq 0
$$

Presently we will relate this criterion to prices and investment. Define

$$
p_{i}(t) \equiv \partial V(t) / \partial K_{i}(t), \text { for all } i .
$$

The variable $p_{i}(t)$ is the (spot) shadow price of the $i^{\text {th }}$ asset at $t$. This price represents the contribution to $V(t)$ made by $K_{i}(t)$ both through the goods and services it helps produce as well as through direct enjoyment of the stock itself. A wetland is an example of a capital asset that contributes to $V$ both ways; health is another. In imperfect economies (e.g., those experiencing

\footnotetext{
${ }^{3}$ For a justification see Dasgupta (2001: Appendix).
} 
the tragedy of the commons) an asset's shadow price can be negative even when its market price is positive. ${ }^{4}$

At any date an asset's shadow price is a function of the stocks of all assets. Moreover, the price today depends not only on the economy today, but on the entire future of the economy. So, for example, future scarcities of natural capital are reflected in current shadow prices of all goods and services. That means that shadow prices are functions of the degree to which various assets are substitutable for one another, not only at the date in question, but at subsequent dates as well. Of course, if the conception of intergenerational well-being involves the use of high discount rates on the well-being of future generations (i.e., if $\delta$ is large), the influence on today's shadow prices of future scarcities would be attenuated. Intergenerational ethics plays an important role in the structure of shadow prices.

Equations (5) and (6) imply that the ratios of shadow prices are marginal social rates of substitution among the various capital assets. In an economy where $V(t)$ is maximized, these marginal rates of substitution equal their corresponding marginal rates of transformation. As the latter are observable in market economies (e.g., border prices for traded goods in an open economy), shadow prices are frequently defined in terms of marginal rates of transformation. However, marginal rates of substitution in imperfect economies do not necessarily equal the corresponding marginal rates of transformation. In our empirical application below, we sometimes use market prices as shadow prices for various forms of capital assets. In cases involving assets over whose production and distribution the market mechanism is known to be especially deficient, we invoke additional information to assess the shadow prices.

\subsection{Comprehensive Wealth}

To arrive at a measure of comprehensive wealth that accounts for certain exogenous changes (e.g., changes in total factor productivity), we need an additional shadow price. Let time also be regarded as a capital asset. Also, let $r(t)$ be the shadow price of time at $t$ :

$$
r(t)=\partial V / \partial t
$$

\footnotetext{
${ }^{4}$ Although we use felicity as our numeraire in this theoretical section, for convenience in our empirical work in Section 5 we use consumption as the numeraire. The sustainability criterion we develop below (Definition 2) is unaffected by the choice of numeraire.
} 
We can now use shadow prices as weights to construct an aggregate index of the economy's stock of capital assets. Refer to that index as comprehensive wealth, $W$. Formally, we have

Definition 2. An economy's comprehensive wealth is the (shadow) value of all its capital assets; that is,

$$
W(t)=r(t) t+\Sigma p_{i}(t) K_{i}(t) .
$$

As observed earlier, comprehensive wealth is the dynamic analogue of real national income and involves the same reasoning as the one that is familiar in studies of the welfare economics of timeless economies.

A critical linkage in our analysis is between changes in comprehensive wealth at constant prices and changes in intergenerational well-being.

Proposition 1. A small perturbation to an economy increases (resp., decreases) intergenerational well-being if and only if holding shadow prices constant, it increases (resp., decreases) comprehensive wealth. ${ }^{5}$

Proof: Let $\Delta$ denote a small perturbation. Then

$\Delta V(t)=[\partial V / \partial t] \Delta t+\Sigma\left[\partial V / \partial K_{i}(t)\right] \Delta K_{i}(t)$.

But by definition, $p_{i}(t)=\partial V(t) / \partial K_{i}(t)$ and $r(t)=\partial V / \partial t$. Therefore, equation (9) can be reexpressed as

$$
\Delta V(t)=r(t) \Delta t+\Sigma p_{i}(t) \Delta K_{i}(t) . \quad \text { QED }
$$

\subsection{Comprehensive Investment}

Now $p_{i}(t) \Delta K_{i}(t)$ in (10) above is the shadow value of net investment in asset $i$, and $r(t)$ is the shadow price of time $t$. Letting $I_{i}(t)=\Delta K_{i}(t) / \Delta \mathrm{t}$, we can write equation (10) as

$$
\Delta V(t)=r(t) \Delta t+\Sigma p_{i}(t) I_{i}(t) \Delta t^{6}
$$

\footnotetext{
${ }^{5} \mathrm{We}$ are considering a closed economy here. Exogenous price changes in the international prices facing a small country that exports natural resources are a different matter. There, capital gains have to be included. See Section 4.2.
} 
Definition 2 says that the expression on the right hand side of equation (11) is the comprehensive investment that accompanies the perturbation. This means that Proposition 1 can be re-stated as

\begin{abstract}
Proposition 2. A small perturbation to an economy increases (resp., decreases) intergenerational well-being at $t$ if and only if the shadow value of comprehensive investment at that accompanies the perturbation is positive (resp. negative). ${ }^{7}$
\end{abstract}

Comprehensive investment has a well-known welfare interpretation. It can be shown that the shadow value of comprehensive investment is measured by the present discounted value of the changes in the consumption services that are brought about by it. In studies on sustainable development the perturbation is the passage of time itself, meaning that $\Delta t>0$. That is the case we study in this paper.

Note that the relationship between intergenerational well-being and comprehensive wealth in Propositions 1 and 2 is an equivalence relation. The claim is that a change in comprehensive wealth has the same sign as the corresponding change in intergenerational wellbeing. The propositions on their own do not determine whether comprehensive wealth in a particular economy can be maintained or whether vital forms of natural capital have been so depleted that it is not possible for the economy to enjoy sustainable development in the future. For example, it could be that, even though an economy experiences sustainable development for a period of time, it is incapable of enjoying it indefinitely owing to scarcity of resources or limited substitution possibilities among capital assets or because the scale of the economy is too large. Or it could be that although the economy is in principle capable of realizing sustainable development, $V(t)$ declines along the path that has been forecast because of bad government policies.

For yet another example, consider an optimum economy, in which $\delta$ has been chosen to be so large that $V(t)$ declines over time. This latter example demonstrates that "sustainability"

\footnotetext{
${ }^{6}$ It may seem odd to regard the first term in equation (11) as investment, since no one in the economy is doing anything other than wait to see the corresponding asset grow. However, as waiting is a cost, it seems to us entirely appropriate to include $r(t) \Delta t$ in the concept of comprehensive investment.

${ }^{7}$ There is no settled term yet for the linear index we are calling "comprehensive investment" here. We are borrowing the term from Arrow et al. (2007), but it has been called "genuine saving" (World Bank, 2006). We believe the term "comprehensive investment" better captures the essential idea.
} 
and "optimality" are very different concepts. It can even be that along an optimum path (i.e., a path that maximizes $V) V(t)$ declines for a period and then increases thereafter.

\subsection{Sustainable Development over an Interval of Time}

Inequality (11) yields a local measure of sustainability. Integrating equation (11) from, say, $s=0$ to $s=T$, yields

$$
V(T)-V(0)=\int_{0}^{T} r(s) d s+\sum_{i}\left[p_{i}(T) K_{i}(T)-p_{i}(0) K_{i}(0)\right]-\int_{0}^{T}\left[\sum_{i}\left(d p_{i}(s) / d s\right) K_{i}(s)\right] d s
$$

Equation (12) says that in assessing whether intergenerational well-being has increased between two dates, the capital gains on the assets that have accrued over the interval should be deducted from the difference in wealth between the dates.

Our empirical applications, reported in Sections 4-5, cover the period 1995-2000. Because the period is short and all the figures for economic variables are period averages, we interpret 1995-2000 to be a moment in time. We thus by-pass capital gains and make use of Definition 1 to determine whether the countries in our sample enjoyed sustained development.

\section{Extensions to the Model}

Here we describe a few extensions to the model. First, we show how those technological and institutional changes that are reflected in an economy's total factor productivity growth can be subsumed in comprehensive investment. Second, we describe how the model can be extended to incorporate population growth without the need for estimating the shadow price of population. Finally, we indicate how the model can allow for transnational externalities.

\subsection{Incorporating TFP Growth in Comprehensive Investment}

Technological change involves investment in research and development (R\&D). Expenditure in R\&D is therefore a part of comprehensive investment. But that does not take into account exogenous increases in TFP growth. Exogenous changes in TFP are reflected in the first term on the right hand side of equation (11), namely $r(t)(=\partial V / \partial t)$. 
Let $Y(t)$ denote aggregate output at $t$. Suppose $Y(t)=A(t) F(\underline{K}(t))$, where $F$ is a constant returns to scale production function and $A(t)$ is TFP at $t$. $A$ can be interpreted to be an aggregate index of knowledge and the economy's institutions. It can therefore be regarded as yet another form of capital asset. Let $\gamma$ be the rate of growth of TFP (that is, $(d A / d t) / A)$. It can be shown that if the economy is in a steady state,

$$
\partial V / \partial t=\gamma q_{A}(t) A(t) /\left[\sum_{i} p_{i}(t) K_{i}(t)\right]
$$

where $q_{A}(t)$ is the shadow price of $A(t)$. If the rate of national saving is small, the factor $q_{A}(t) A(t) / \Sigma p_{i}(t) K_{i}(t)$ can be shown to equal 1 approximately. In that case equation (13) says that we need merely add TFP growth to comprehensive investment (equation (11)). We follow this procedure in our empirical application.

\subsection{Population Change}

Population is a capital asset. We have ignored it so far because population has been assumed to remain unchanged over time. Demographic change introduces complications to the analysis because we now have to add to the list of capital assets a set of (demographic) capital stocks whose shadow prices have to be estimated. This means adding to the list of capital assets the size of each cohort in the population. For simplicity we assume that cohorts are identical in their preferences and abilities. Then the size of the population, $P(t)$, is the stock of the demographic asset. Arrow et al. (2003) developed the basics of the required analysis when a demographic theory is in hand. In the absence of a sound demographic theory we suppose that $P(t)$, like TFP, changes exogenously over time. The effect of changes in $P$ would then appear in the term $r(t)$ in equation (11). It remains to find a workable way to estimate that effect and isolate it from all other factors included in $r(t)$. To do that it is simplest to assume that excepting for population change, the economy does not experience any exogenous changes.

It could seem intuitive that when population size changes, the criterion for sustainable development should be non-declining comprehensive wealth per capita. It transpires that this is generally not true (Dasgupta, 2001; Arrow et al., 2003). In what follows we identify conditions under which the intuition is correct.

Consider the following expression for intergenerational well-being: 


$$
V(t)=\frac{\int_{t}^{\infty} P(s) U(c(s)) e^{-\delta(s-t)} d s}{\int_{t}^{\infty} P(s) e^{-\delta(s-t)} d s}
$$

where $c(s)$ represents per-capita consumption at time $s$. Let us call the ethical theory on which expression (14) is based, dynamic average utilitarianism.

Note that the denominator in expression (14) would play no role in policy evaluation at $t$, because the denominator would simply be a scale factor attached to expression (14). But for sustainability analysis the denominator matters, because the evaluation there is undertaken across time.

Let $k_{i}(t)=K_{i}(t) / P(t)$ represent the per capita stock of asset $i$ and let $\underline{k}(t)$ be the vector of per capita stocks. Because population has been assumed to change at a constant rate and because by assumption the only exogenously changing variable is population, expression (14) can be written as

$$
V(t)=V(k(t), P(t)) .
$$

It can be shown that if in addition, each of the equations reflecting the economy's dynamics can be expressed in terms solely of per capita capital stocks, then $\partial V(t) / \partial P(t)=0$ (Dasgupta, 2001; Arrow et al., 2003). Under those conditions we therefore have

Proposition 3. Development is sustained at $t$ if and only if, when valued at constant shadow prices, comprehensive wealth per capita is non-decreasing at $t$.

The assumption that each of the equations reflecting the economy's dynamics can be expressed in terms solely of per capita capital stocks is very strong. In order to weaken it and nevertheless obtain a tractable formula, suppose the scale economies of production are such that population size enters the economy's dynamics as total factor productivity. In that case we would modify Proposition 3 by adding the percentage rate of change of population size to the rate of change in wealth. Proposition 3 and its extension just mentioned have been used in applied studies on sustainable development (Arrow et al., 2004, 2007).

\subsection{Transnational Externalities}


Countries interact with one another not only through trade in international markets, but also via transnational externalities. In our empirical application we subtract from growth in wealth the damages caused to a country by anthropogenic climate change. Hamilton and Clemens (1999) included carbon dioxide in the atmosphere in their list of assets, but regarded the shadow price (a negative number) of a country's emission to be the sum of the shadow prices of all countries. Their procedure would be valid if each country were engaged in maximizing global welfare, an unrealistic scenario. We now develop the required analysis for global public goods generally.

Let $G(t)$ be the stock of a global public good at $t$. We may imagine that $G$ is measured in terms of a "quality" index which, to fix ideas, we shall regard as carbon dioxide concentration in the atmosphere. Being a global public good, $G$ is an argument in the $V$ function of every country. For simplicity, we assume that there is a single private capital good. Let $K_{n}(t)$ be the stock of the private asset owned by residents of country $n$. If $V_{n}$ is intergenerational well-being in $n$, we have in the notation of the previous section,

$$
V_{n}(t)=V_{n}\left(K_{n}(t), G(t), t\right) .
$$

Let $g_{n}(t)=\partial V_{n}(t) / \partial G(t)$. It may be that $G$ is an economic "good" for some countries, while it is an economic "bad" for others. For the former, $g_{n}>0$; for the latter, $g_{n}<0$. Let $E_{n}(t)$ be the net emission rate from country $n$ and $E(t)$ the net aggregate emission rate. It follows that

$$
d G(t) / d t=\Sigma E_{n}(t)=E(t) .
$$

Comprehensive investment in country $n$ is $d V_{n}(t) / d t=r_{n}(t)+q_{n}(t) d K_{n}(t) / d t+g_{n}(t) d G(t) / d t$, which, on using (17), becomes:

$$
d V_{n}(t) / d t=r_{n}(t)+q_{n}(t) d K_{n}(t) / d t+g_{n}(t) \Sigma E_{n}(t) .
$$

Note that the expression on the right hand side of equation (18) does not depend on whether the world economy is enjoying optimum international cooperation. On the other hand, $\mathrm{d} K_{n}(t) / \mathrm{d} t$ and $\mathrm{d} G(t) / \mathrm{d} t$ do depend on the policies followed in other economies (e.g., whether the countries cooperate) and they affect $r_{n}(t), q_{n}(t)$ and $g_{n}(t)$. Hamilton and Clemens (1999) and World Bank (2006) identified the "net benefit" to country $n$ from emissions as $\left(\Sigma g_{k}(t)\right) E_{n}(t)$, whereas, as equation (18) shows, the correct formula is $g_{n}(t)\left[\Sigma E_{k}(t)\right]$. If countries act in their own interest, the two expressions are equal only under very special circumstances (e.g., if the countries were identical). 


\section{Implementing the Theory: Measuring Changes in Capital Stocks and Estimating Shadow Prices}

In an important publication, World Bank (2006) built on the empirical analysis in World Bank (1997) by estimating wealth and it composition in 120 nations in year 2000.

Comprehensive wealth was defined by the authors as the present value of the flow of aggregate consumption. The authors forecast growth rates in consumption for the foreseeable future starting 2000 so as to estimate comprehensive wealth. They then estimated the shadow values of reproducible capital and natural capital and deducted the sum from comprehensive wealth to arrive at a figure for what they referred to as the value of "intangible capital" (human capital, institutions, public knowledge). Natural capital was taken to include agricultural land, urban land, pasture land, energy and mineral resources, timber and non-timber forest resources, and protected areas. They found that in poor countries the shadow value of natural capital is about 25 per cent of comprehensive wealth and that the share of intangible wealth is a bit over 55 per cent.

Our approach differs from that of the World Bank in that we calculate comprehensive wealth directly from the values of the stocks of various forms of capital rather than from forecasts of a time-profile of future consumption. As is well known, the present value of the flow of aggregate consumption can only be identified with comprehensive wealth (the shadow value of an economy's entire set of capital assets) under stringent conditions. ${ }^{8}$

Our approach also differs in the ways we calculate various components of comprehensive investment. First, we estimate investment in human capital with reference to projected changes in the work force and in labor productivity; in contrast, the World Bank identified investment in human capital with public expenditure in education. Second, we consider improvements or deteriorations in health, which were not part of the World Bank assessments. Third, we account for capital gains in our calculations of changes in wealth across various nations. In contrast, the World Bank implicitly assumed that the first term on the right hand side of equation (11) was zero (that is, $r(t) \Delta t=0$ ); hence, for example, in calculating the change in wealth held in the form of oil and mineral resources, the capital gains (or losses) that should be applied to reserves were

\footnotetext{
${ }^{8}$ One must assume, for example, that all transformation possibilities (including the production of ecosystem services) are subject to constant returns to scale.
} 
not considered. Finally, in contrast with the World Bank we allow for total factor productivity to differ across nations. In this section we describe how we implement these elements of our analysis.

For our empirical application we need to measure levels and changes in the stocks of various types of capital. In addition, we need to be able to aggregate those levels and changes to obtain estimates of comprehensive wealth and comprehensive investment. This requires applying shadow prices to each of the various stocks. Here we describe our methods for capital stocks, changes in those stocks, and shadow prices.

\subsection{Valuing Net Investment in Natural Capital}

To arrive at values of net investment in natural capital we need to estimate changes in resource stocks as well as the shadow prices to apply to those changes. For a nonrenewable resource such as copper, the change in the stock is simply the negative of the amount depleted (extracted) during the period. If we abstract from externalities associated with the use of the resource, the rental value will correspond to the resource's shadow price.

For renewable resources such as forests, net investment equals the increase in the forests due to natural growth and replanting, less the amount that is depleted. The shadow price is again the rental value (price less cost of cutting).

\subsection{Capital Gains in Nonrenewable Resources}

Oil exporting countries have enjoyed capital gains on their stocks underground. To the extent that the rental value of a nonrenewable resource rises over time, owners of the resource stock should expect to receive capital gains. Correspondingly, future consumers should expect to pay higher real prices which, other things being equal, imply a reduction in real wealth. Thus the impacts on real wealth of a given nation's residents will depend on the extent to which the residents own (and sell) or consume (purchase) the resource in question. 
It appears that those impacts have not been addressed in any of the prior literature. ${ }^{9}$ For each country, the capital gain is equal to the resource stock times the rate of increase of the export price. We equate this shadow value to current resource rents and, following Hotelling, assume that this shadow price rises at the rate of interest. Summing the capital gains over all countries gives the total capital gains to that resource. The corresponding capital losses by purchasers must equal this sum. In principle, these losses should be allocated among individual countries in accordance with their future purchases of oil. In the empirical application below we have approximated by giving each country a capital loss equal to total capital losses to consumer times that country's share of current consumption. It should be noted that in a closed economy there is no need to adjust for capital gains or losses, since the future gains to owners will be exactly offset by the losses to future consumers.

\subsection{Determining the Values of Stocks of Human and Health Capital}

Here we are concerned with two aspects of human capital: education and health. Each is simultaneously a productive factor and a constituent of well-being. In other words each is both a means and an end. In what follows we simplify our empirical work by regarding education solely as an input in the production of well-being and health solely as a constituent of well-being.

\subsubsection{Human Capital}

We follow the methods introduced by Klenow and Rodríguez-Clare (1997), methods that build on the earlier work of Mincer. It is assumed that investments in education earn a market rate of interest for the period of education. Assuming a steady state as a first approximation, the amount of human capital per worker is proportional to $\exp (r T)$, where $r$ is the appropriate rate of interest (taken to be 8.5 percent per annum) and $T$ is the average number of years of educational attainment. The stock of human capital is the human capital per worker multiplied by the number of workers. This quantity is adjusted for mortality during the working life.

\footnotetext{
${ }^{9}$ In particular, Arrow et. al. (2004) did not take account of the capital gains to countries with large oil reserves. As a result, that study might have understated the sustainability of Middle East countries (see Table 2, p. 163, and discussion on p. 165).
} 
We assume that the labor market is sufficiently competitive to assure that the marginal productivity of human capital equals its shadow price and the real wage. Hence the shadow price of human capital is equal to the total real wage bill divided by the stock of human capital.

\subsubsection{Health}

Our approach to health is based on life expectancy: an increase in life expectancy translates into an improvement in health. ${ }^{10}$ More specifically, the value of health improvements is the value that people attach to the additional years of life that result from such improvements. To calculate the value of an additional life year, we start with estimates of the value of a statistical life (VSL). A common method for estimating VSL is to study differential wages for jobs involving differential risks of a fatal on-the-job accident.

Given the VSL, we can derive the value to individuals of an additional life year. ${ }^{11}$ Suppose for simplicity that the value to someone of an additional year of life, $h$, is independent of age, $a$. Assuming that the time discount rate is $\delta$, we can express the value $V$ for an individual of age $a$ to survive to age $T$ as

$$
V(a, T)=h \int_{a}^{T} e^{-\delta(s-a)} d s=h\left(1-e^{-\delta(T-a)}\right) / \delta
$$

Let $f(T)$ be the probability density that someone born will die at age $T$, and let $F(T)$ be the corresponding cumulative distribution. If $f(T / T \geq a)$ is the conditional probability density of death at age $T$, given survival to age $a$, then

$$
f(T \mid T \geq a)= \begin{cases}0 & , T<a \\ f(T) /[1-F(a)] & , T \geq a\end{cases}
$$

Let $m(T)$ be the mortality hazard rate (the probability rate that someone aged $T$ will die at that age), and define

$$
M(T)=\int_{0}^{T} m(s) d s .
$$

Then we have the identity,

$$
f(T \mid T \geq a) \equiv m(T) e^{M(a)-M(T)}
$$

\footnotetext{
${ }^{10}$ We do not adjust for changes in the quality of life. Such adjustments are embodied in the concept of a quality adjusted life year (QALY), a measure that has been adopted by the World Health Organization and other agencies.

${ }^{11}$ Our approach is an extension of approaches taken by Nordhaus (2002) and Becker et al. (2005). Ideally we would like estimates of the age-dependent value of an additional life-year, which is what is attempted in Murphy and Topel (2006) for the U.S. Limitations of data in the other countries in our sample prevent us from attempting that here.
} 
From equations (19)-(22) we arrive at our measure of the value of health capital, $H(a)$, of an individual of age $a$ : it is the expected value of survival to a random age. Thus,

$$
\begin{aligned}
H(a)= & \int_{a}^{\infty} V(a, T) f(T \mid T \geq a) d T, \text { or } \\
& H(a)=h\left[1-\int_{a}^{\infty} e^{-[\delta(T-a)+M(T)-M(a)]} m(T) d T /\right] \delta .
\end{aligned}
$$

Let $\pi(a)$ be the proportion of people of age $a$. Then the per capita health capital in the economy, measured in life years, is $\int_{0}^{\infty} \pi(a) H(a) d a$. This is the same as the VSL. Therefore we choose the parameter $h$, the age-independent value of a statistical life year, in each country so as to insure this equality.

\section{Data and Empirical Results}

We use data from the period 1995-2000 to analyze whether economic development was sustainable in five countries: the United States, China, Brazil, India, and Venezuela.

\subsection{Natural Capital}

Natural capital includes nonrenewable energy and mineral resources as well as renewable forest and land resources. We focus on the economically most important types of natural capital, to the extent that data are available.

\subsubsection{Oil and Natural Gas}

We obtain estimates of oil and natural gas consumption, extraction, and proven reserves from the Statistical Review of World Energy (BP, 2005). Proven reserves are the known quantity that is economically recoverable given current technology. ${ }^{12}$ Our measure of the stock in year $t, K(t)$, uses the total extraction, $X(t)$, for that country and the most recent measure of proven reserves, $K(T)$, according to:

\footnotetext{
${ }^{12}$ The annually reported proven reserves are the best available basis for estimating oil and gas stocks. However, it is worth noting that such reserves are imperfect measures of stocks because they do not account for future discoveries and technological improvements. While a large amount of oil and natural gas is extracted each year, new oil and natural gas field discoveries and new extraction technology increase the proven reserves.
} 


$$
K(t)=K(T)+\sum_{j=t}^{T-1} X(j)
$$

As a simplification, we treat oil as a homogenous good, averaging over oil grades (West Texas, Nigerian Forcados, Brent, and Dubai) and over time to obtain an average price of oil for the 1995-2000 period. The average price for natural gas is also calculated as an average price over sources (US, UK, Japan, Europe) and over time. The shadow price is this average price less the extraction cost which is country specific and is obtained for both oil and natural gas from the World Bank (2006) data appendix.

\subsubsection{Metals and Minerals}

For metals and minerals, we use the reported proven and probable reserves from the Mineral Commodity Summaries (U.S. Geological Survey, 2006). Extraction estimates for each commodity is obtained from the World Bank (2006) data appendix. The measure of the stock for each metal and mineral in each year is calculated using only the most recent measure of the proven reserves and the extraction data as in Equation (28). World market prices and country specific extraction cost estimates are from the World Bank (2006) data appendix. For certain metals and minerals, the country specific extraction cost estimate exceeds the average world market price. If this is the case, we assume that the shadow price for this resource in this country is zero, even if the country is extracting this resource.

\subsubsection{Forests}

We obtain the total cubic meters of commercially available forests from the Global Forest Resources Assessment (Food and Agriculture Organization, 2005) for 1990 and 2000 and impute commercially available forest cover linearly for intermediate years. The data show that while commercially available forest cover is declining globally, it is increasing in the US, China, and India. We use the commercially available forest cover as a measure of the quantity of timber available in that country. By doing so, we are implicitly assuming that the density of wood per hectare is relatively constant. The shadow price for timber is the average market price less the extraction cost; the price and cost data are obtained from the World Bank (2006) and are country specific. The market price of timber is country specific because different types of wood have vastly different valuation and there are differences in the composition of forests by country. 
Forests are valued not only for the wood that can be extracted from them, but also for the recreation, erosion control, water filtration, and habitat services they provide. The World Bank (2006) offers two estimates of annual non-timber forest benefits per hectare, one for developing countries and one for more industrialized nations. Similar to commercially available forest cover, we obtain the total forest cover for each country from the Food and Agriculture Organization (2005) for 1990 and 2000 and impute total forest cover linearly for intermediate years.

\subsubsection{Land}

One of the most important forms of natural capital, in terms of its total value, is land. Countries differ in their land endowments, both in area and type (e.g., agricultural, forest, urban). The World Bank (2006) provides estimates of the quantity and value of four types of broadly defined land: forests, protected areas, cropland, and pastureland. We do not attempt to include the value of urban land and do not have the data necessary to calculate the change of land use. Thus we treat land as fixed in composition and value for each country.

\subsubsection{Consolidation: Levels and Changes in Stocks of Natural Capital}

Table 1 indicates the levels and changes in the stocks of the various types of natural capital we have considered. ${ }^{13}$ Interestingly, the value of forests is greater than the value of oil in all but one of the five countries we are considering; Venezuela is the exception. For each country except the U.S., the total natural capital decreased between 1995 and 2000. In the U.S., the increase in forest area, especially commercially available forest area, offset the large declines in other forms of natural capital, particularly oil and natural gas. Of the five countries, Venezuela experienced the greatest decline in natural capital during this period, extracting 3.1 percent of its total measured natural capital.

\subsection{Oil Capital Gains}

\footnotetext{
${ }^{13}$ If there is no information listed for a commodity, this means that the country-specific estimate of the extraction cost exceeded the world average market price.
} 
In calculating the capital gains on stocks of oil, we allow the shadow price of oil to increase by five percent per year over the period 1995-2000. We apply this increase in the shadow price of oil to the initial (year 1995) oil stock. Thus, the overall change in the value of the oil stock is $p_{K}(t) I(t)+\dot{p}(t) K(t-1)$, where $I(t)$ is the change in the stock from period $t-1$ to $t$ and $\dot{p}(t)$ is the change in the shadow price over this interval.

The capital gains to owners of oil are higher prices to consumers of oil. Thus, capital gains imply a redistribution of wealth from oil consumers to oil producers. We allocate the reduction to consumers' wealth by taking the world total of capital gains and distributing it as a loss to each country according to that country's share of world oil consumption. We obtain the level of proved oil reserves, oil extraction, and oil consumption for nearly every country from the Statistical Review of World Energy (BP, 2005) and calculate the level of oil reserves in 2000 as in Equation (28). Oil capital gains are computed from the 2000 level of oil reserves. We use the average oil consumption from 1995 to 2000 divided by the sum over all countries as the measure a country's fraction of world total oil consumption.

\subsection{Reproducible Capital}

The estimated stocks of reproducible capital for the five countries are taken from the data appendix to Klenow and Rodríguez-Clare (2005). Our approach to reproducible capital differs from earlier work by the World Bank (2006) and by Arrow et al. (2004) by accounting for crosscountry ownership. Some of the stock of reproducible capital in a country is owned by investors outside of that country. Correspondingly, some of the reproducible capital outside a given country is owned by the residents of that country. Our notion of sustainability focuses on the changes in the productive base owned by a given country's residents. Thus it is important to consider changes in a country's net asset position.

In the U.S., net holdings of international assets are reported by the BEA. In developing countries, although capital flows are closely monitored, little work has been done on measuring the accumulated stocks of foreign assets and liabilities. A recent paper by Lane and MilesiFerretti (2007) provides estimates of net holdings of international assets from balance of payments and other IMF data. We use their estimates in our analysis. 


\subsection{Human Capital}

Here we apply the approach to valuing human capital described in subsection 4.3.1. The key empirical inputs include the assumed rate of return on human capital and the level of educational attainment. For all countries we apply a value of 0.085 for the former. For the latter, we use an annual measure of the average years of educational attainment for the adult population from the data appendix of Klenow and Rodríguez-Clare (2005). The average educational attainment, measured in years, for the adult population in India increased by an incredible 12 percent from 1995 to 2000. Brazil, China, and the U.S. had smaller increases as 9.7 percent, 4.1 percent, and 1.4 percent, respectively. Venezuela was the only country of the five we considered to have a decline in the average education level.

The average amount of human capital per worker is multiplied by the total population of the country that is old enough to have obtained the average level of education. It is important to recognize that all adults, not only those who are currently employed, have human capital. Thus, the total stock of human capital increases if the average level of education increases, or if the number of adults increases. It is for the latter reason that the total human capital stock in Venezuela increased by 12.1 percent over the period even though the average level of education declined by 0.8 percent.

The shadow price of a unit of human capital is equal to the discounted sum of the wages it would receive (the rental price) over the expected number of working years remaining. To calculate the rental price for a unit of human capital, we calculate the employed human capital for a country as the average amount of human capital per worker multiplied by the number of workers. This is divided by the total wage bill to obtain a country specific annual rental price for a unit of human capital. The total wage bill in the U.S. is obtained from the BEA national income accounts. ${ }^{14}$ The total wage bill in China is not reported, so this is calculated from information provided by the 2002 China Statistical Yearbook. ${ }^{15}$ The total wage bill for Brazil, India, and Venezuela is calculated as the average wage from the Occupational Wages around the World Database multiplied by the total level of employment.

\footnotetext{
${ }^{14}$ Available online from the Bureau of Economic Analysis at http://www.bea.gov/national/Index.htm

${ }^{15}$ Available online from the National Bureau of Statistics of China at http://www.stats.gov.cn/english/statisticaldata/
} 
The expected number of working years remaining is calculated using current age-gender participation and mortality rates. Mortality and labor force participation rates by gender vary considerably by country. We use the year 2000 World Health Organization life tables ${ }^{16}$ and the 1990 US Census Bureau IDB demographic data ${ }^{17}$ to calculate the expected number of working years remaining for men and women by age in each country. The discount rate for future wages is set to 0.085 . The resulting shadow price of a unit of human capital is greater than $\$ 100,000$ for the U.S. and less than $\$ 10,000$ for China and India. The large difference in this shadow price is due to differences in the discounted expected earnings potential for workers in different countries.

\subsection{Environmental Capital}

Extraction of natural capital and creation of manufactured wealth results in environmental externalities, such as water and air pollution. These externalities are analogous to a drawdown of wealth. We focus on one type of environmental externality, climate-related damages. Unlike other forms of natural capital, we do not attempt to estimate the total level of the environmental asset (in this case the global atmosphere); rather, we consider only the change in environmental capital.

To apply the procedure described in the previous section, we need data on global emissions of greenhouse gases during the period 1995-2000, as well as on the damage to each of the individual countries associated with these emissions. Note that the damages from these current emissions need not occur during the five-year period: future damages attributable to current emissions (through the impact on future atmospheric concentrations) are relevant to current calculations of changes in wealth. We obtained global carbon dioxide emissions from fossil fuel consumption and manufacturing from the 2007 World Development Indicators data. ${ }^{18}$ Carbon dioxide emissions from deforestation were calculated using data from the Food and Agriculture Organization (2006) and Houghton (2005). Our measure of total carbon dioxide emissions over the $1995-2000$ period is 35.5 billion tons and likely underestimates the true

\footnotetext{
${ }^{16}$ Available online at http://apps.who.int/whosis/database/life_tables/life_tables.cfm

${ }^{17}$ Available online at http://www.census.gov/ipc/www/idb/informationGateway.php

${ }^{18}$ Available online at http://web.worldbank.org/
} 
emissions over this period as key sectors are not included, and we used conservative estimates of carbon emissions from deforestation.

Following Tol (2009), we assume that the damage from global emissions is $\$ 50$ per ton carbon. ${ }^{19}$ We consider alternative values in a sensitivity analysis. Combining the damages-perton and emissions data, we arrive at total damages of $\$ 1,840$ billion for this five-year period. We allocate these total damages to the five countries using the estimates from Nordhaus and Boyer (2000). This study apportions the damages to each country as follows: the U.S. bears 9 percent of global loss, India bears 5 percent, Brazil bears 2 percent, China and Venezuela both bear less than 1 percent.

\subsection{Overall Changes in Capital: Comprehensive Investment}

Table 2 consolidates the changes in all of the forms of capital we have considered. As mentioned, in all countries except the U.S., the overall change in the value of natural capital is negative. Yet comprehensive investment is positive in all countries. In all countries except China, changes in human capital are the most important contributor to comprehensive investment, and these changes outweigh the negative influence of natural capital depletion. In the U.S., for example, human capital augmentation accounts for about 83 percent of comprehensive investment -- $\$ 4.7$ trillion of the $\$ 5.7$ trillion billion total.

In Venezuela, the largest changes in capital stocks are those relating to natural capital. Despite very large reductions in natural capital, comprehensive investment is positive in this country. This is partly due to sizeable capital gains on oil stocks. Without these capital gains, Venezuela's comprehensive investment would be negative. Perhaps surprising is the result that China enjoys the highest comprehensive investment among the five nations, driven by a 75 percent increase in reproducible capital over the five year period.

It should be emphasized that a key element of these calculations is the shadow or accounting price applied to each type of capital. These indicate the rate at which one form of capital can substitute for another. If the shadow prices for natural capital, in particular, are too low (high), our results will understate (overstate) the lost wealth from depletion in natural

\footnotetext{
${ }^{19} \mathrm{Tol}$ (2009) is a meta-analysis of 232 studies on the social cost of carbon. The weighted mean social cost of carbon across the studies at a 3 percent pure rate of time preference is $\$ 50$ per ton. This is the same as a social cost of $\$ 13.64$ per ton of carbon dioxide.
} 
resource stocks. It should also be noted that these calculations do not account for many healthrelated elements. We discuss this issue further below.

\subsection{Accounting for Population Growth and Technological Change}

We next adjust the changes in comprehensive wealth to account for population growth and technological change. The first column of Table 3 reproduces the growth rate of comprehensive wealth from Table 2. The second column indicates the annual population growth rate in each country over the interval 1995-2000. Column 3 subtracts this growth rate from the rate in column 1 to arrive at the per-capita growth rate of comprehensive wealth.

We find that Venezuela and Brazil have a negative per-capita growth rate of comprehensive wealth. As indicated in Column 1, both countries experienced an increase in comprehensive wealth; however, comprehensive wealth did not grow as much as population did. For the U.S., China, and India, we find that comprehensive wealth grew at a more rapid pace than population.

The columns numbered 4 and 5 in Table 3 account for technological change. Under the assumptions indicated in Section 3.1, the appropriate adjustment for technological change is obtained by adding the TFP growth rate from the initially obtained growth rate of per-capita comprehensive wealth. Column 4 reports the TFP growth rate obtained from Klenow and Rodríguez-Clare (2005). Column 5 reports the per capita comprehensive wealth growth rate adjusted for TFP growth.

The numbers in Column 5 are our ultimate indicators of whether the sustainability criterion is met (without attention to changes in health). According to our calculations, each nation except for Venezuela satisfies the criterion. For comparison, we report the per capita annual GDP growth rate in Column 6.

Several of these results may surprise. We estimate a per capita comprehensive growth

rate (Column 3) that is positive but close to zero for the U.S. The cost of oil net capital gains due to the large share of world oil consumption is significant for the U.S. It is the estimated TFP growth that accounts for most of the increase in TFP-adjusted per capita comprehensive wealth.

For China, we estimate a fairly high rate of growth of comprehensive wealth, both overall (Column 1) and in per capita terms (Column 3). The high growth rate of comprehensive wealth 
derives in large part from that nation's significant increase in reproducible capital (evaluated at shadow prices) over the period 1995-2000, as shown in Table 2. In addition, estimated TFP growth for China is very significant at 2.71 percent. This also contributes to the high estimate (5.63 percent) for China's TFP-adjusted per capita comprehensive wealth growth rate (Column $5)$.

India is quite similar to China in that the growth in comprehensive wealth is primarily due to investment in reproducible and human capital. Growth in reproducible capital is lower, population growth in India is higher, and TFP growth is lower than for China. These factors lead to the more moderate estimate ( 2.70 percent) for India's TFP-adjusted per capita comprehensive wealth growth rate.

For Brazil, it is the increase in human capital that accounts for nearly all the growth in comprehensive wealth. The minuscule investment in reproducible capital is less than half the loss of natural capital (primarily due to deforestation). Human capital in Brazil is growing at a rate that is only slightly more than the rate of population growth, leading to the result of a loss of per-capita comprehensive wealth growth. After adjusting for TFP growth ( 0.15 percent), our measure of comprehensive wealth growth is still close to zero, although now slightly positive.

Venezuela had very little investment in human and reproducible capital over the fiveyear period. The primary growth in comprehensive wealth is due to the estimated increase in scarcity rents for Venezuela's oil. The projected increase in the value of oil is not enough to offset the increase in population. Adding the estimated negative TFP growth yields a significantly negative per-capital comprehensive wealth growth rate.

\subsection{Health Capital Considerations}

Here we implement a discrete-time version of the approach to valuing health capital described in Section 4.4.2. Using the World Health Organization life tables, we calculate the conditional density of age of death for each age and country for the year 2000 and 2005. Data from 1995 are not available, so we assume that the difference in mortality between 2000 and 2005 is equal to the difference in mortality between 1995 and 2000 . The value of the health capital for an individual is the expected discounted years of life remaining multiplied by the value of an additional year of life (which is assumed to be independent of age). We use the year 
2000 country-specific population and mortality data along with a country-specific estimate of the value of a statistical life to calculate $h$, the value of an additional year of life. We then use the year 2005 mortality data for each country to compute the change in the expected discounted years of life remaining and then multiply this by the country-specific $h$ calculated using the year 2000 data in order to value the change in mortality.

Two assumptions are needed in order to compute the value of $h$ for each country. First, we assume that individuals use a discount rate of 0.05 in valuing future years of life. Second, we assume a value of a statistical life (VSL) for each country. We perform sensitivity analysis to both of these assumptions in Section 5.9. We use the EPA estimate for VSL in the U.S. of $\$ 6.3$ million in the year 2000. Viscusi and Aldy (2003) performed a cross-country meta-analysis and concluded that the value of a statistical life in other countries is approximately proportional to the 0.6 power of per capita GDP. Thus, for China, Brazil, India, and Venezuela, we assume that the value of a statistical life is proportional to $\$ 6.3$ million at the 0.6 power of the ratio of percapita GDP to the U.S. per-capita GDP. This implies a value of a statistical life for Brazil of $\$ 2.4$ million, for Venezuela of $\$ 2.1$ million, for China of $\$ 1.7$ million, and for India of $\$ 1.3$ million. ${ }^{20}$

Given these assumptions, we use the population and mortality data to calculate $h$, the value of an additional year of life for each country:

$$
h=V S L /\left[\sum_{a=0}^{100} \pi(a)\left(\sum_{T=0}^{100} f(T \mid T \geq a)\left(\sum_{t=0}^{T-a}(1-0.05)^{t}\right)\right)\right]
$$

This value of a statistical life year is the shadow price of a unit of health capital and like the other shadow prices is kept constant over the five year period. As shown in equation (25), the population data $\pi($ a) as well as the conditional mortality data $f(T \mid T \geq a)$ are truncated at 100 years of age. As in Section 4.3.2, $a$ is the age of the individual, $T$ is the year of death, and $t$ indicates time in years.

Using year 2005 mortality data, we re-compute the denominator of the right hand side of equation (25) for each country and multiply it by $h$. Then by subtracting the VSL for that country, we arrive at the per capita change in the value of health capital.

\footnotetext{
${ }^{20}$ As part of the sensitivity analysis in the next section we perform the health calculations under the assumption that the value of a statistical life is the same in all five countries.
} 
Note that we are calculating the change in mortality rates from cross sectional data. Thus, the differences in observed mortality rates reflect historical differences in the environment and in health-provision services. The (higher) mortality rate of a 50 year old relative to a 20 year old reflects the environmental conditions and health services available to the 50 year old throughout his lifetime. We use this information to project the mortality rate of a current 20 year old 30 years in the future; that is, when he reaches 50 . To the extent that future environmental conditions or health-provision services do not mimic those of the past, our estimates may underor overstate the actual changes and the estimated changes in health capital. Future improvements in health services imply that our estimates may underestimate health capital. On the other hand, continued environmental deterioration would imply an opposite bias.

Table 4 indicates that over this five year period, the average health capital of the population (the expected discounted years of life remaining) increased for each of the five countries we considered, reflection mortality improvements. However, the U.S. actually has the lowest per-capita expected discounted years of life remaining of the five countries (rows 1 and 2). This is because the average person in the U.S. is older and faces higher mortality rates. China experienced the most modest mortality improvements, both in percentage and absolute terms.

It Table 5 we present the components of comprehensive investment, including health capital, in per capita terms. For each country, the value of health capital (the level, not the change) is an order of magnitude larger than the combined value of all other forms of capital. For the U.S., the per-capital value of health capital is $\$ 6.3$ million (the value of a statistical life) as compared to about $\$ 20$ thousand for natural capital, $\$ 50$ thousand for reproducible capital, and \$225 thousand for human capital. This is an important point, one that is robust to sensitivity analysis. For the U.S., one would need to assume that the value of a statistical life was about $1 / 20^{\text {th }}$ the size of the value given in the literature in order for the per-capita value of health capital to be similar in value to theother forms of capital. The intuition here is that, on average, Americans own 6.3 million dollars of health capital each, but only 0.3 million dollars of all other forms of capital - including human capital.

What matters for sustainability are the changes in the values of the various forms of capital. According to our estimates, all five nations experience gains in health capital. For all of the countries except Venezuela, the increases in per capita health capital are larger than the per 
capita change in any other form of capital. For Venezuela, the increase in per capita health capital is smaller than the loss in per capita natural capital.

Accounting for health importantly affects the estimates for the growth rate in per capita comprehensive wealth. Before adjusting for TFP growth, this growth rate is small and positive for each country once health is accounted for. This is because health gains were small and positive for each country and health capital dominates all other forms of capital combined. However, Venezuela would still fail the sustainability criterion due to the negative TFP growth rate estimate.

Displaying the other forms of capital in per capita terms as in Table 5 reveals some other interesting features. For example, the natural capital decrease in Venezuela appears much more severe in per capita terms because the population increased by over 10 percent during the 19952000 period. Note also that in the United States, while the loss of natural capital comes to only about one thousand dollars per person, the oil capital loss (due to the increase in future prices) is nearly five times that amount.

\subsection{Sensitivity Analysis}

Table 6 displays the sensitivity of our results for per-capita comprehensive wealth to important parameters. Panel A of the table indicates that the results are robust to the assumed value of the social cost of carbon. Raising the value to $\$ 100$ per ton from our previously employed value of $\$ 50$ per ton has only a minor affect on the per-capita comprehensive growth rate for each country. In most countries, increases in human and reproducible capital have a considerably larger impact on comprehensive investment than the negative contribution from $\mathrm{CO}_{2}$ emissions. For the U.S., the social cost of carbon would need to be nearly $\$ 500$ per ton of carbon for carbon damages to completely offset the per capita gains in reproducible capital alone, although this would push the growth rate of per-capita comprehensive wealth negative before accounting for TFP growth. Note that this assumption has very little effect on China because a relatively small fraction of global carbon damages are allocated to China (Nordhaus and Boyer (2000)).

Panel B focuses on the implications of including or excluding health capital in the calculation of per-capita comprehensive wealth. With or without health capital included, China, 
India, and the United States have large growth rates; Brazil has a small growth rate; and Venezuela has a fairly rapid decline in per capita comprehensive wealth. Note that it is the TFP adjustment that preserves these conclusions. Without the TFP adjustment, for Brazil and Venezuela the sign of the growth rate of per-capita comprehensive wealth depends on whether health capital is included. The level of health capital is much higher than all the other components of comprehensive wealth combined. As a result, the growth rate of health capital has a significant influence on the growth rate of per-capita comprehensive wealth. Without the TFP adjustment, the per-capita comprehensive wealth growth rate simply collapses to the percapita health capital growth rate when health capital is included. Health capital swamps all other forms of capital in importance.

Panel $\mathrm{C}$ indicates the sensitivity to the discount rate applied to the value of additional years of life from health improvements. Results are not highly sensitive to this rate. Using a higher discount rate slightly lowers the growth rate for per capita comprehensive wealth.

Panel D considers alternative values for a statistical life (VSL). Over the range of values considered, there is very little change in the results. Health capital is so much larger than the other forms of capital that its growth rate largely determines the growth rate of all capital (comprehensive wealth) even when the magnitude of human capital is assumed to be smaller through a smaller VSL. For the U.S., one would need to assume a VSL of less than $\$ 0.7$ million for the increase in health capital to approximately equal the increase in reproducible capital. A value this small is far below the range of estimates of VSL in the literature and it would still leave the value of health capital more than twice as large as all other forms of capital combined. One of our main conclusions is that health capital is very large relative to other forms of capital, and that its growth rate largely determines the growth rate of comprehensive wealth.

\section{Conclusion}

This paper has presented and applied an original framework for determining whether a given nation satisfies a reasonable criterion for sustainability. We define sustainability in terms of the capacity to provide well-being to future generations. The indicator of this capacity is a comprehensive measure of wealth - one that includes both marketed and non-marketed assets. 
The sustainability criterion is satisfied if this comprehensive wealth measure is increasing on a per-capita basis.

We advance the theory of growth accounting by providing a consistent framework that incorporates population growth, technological change, human capital, and environmental quality. Two additional innovations are the treatment of health as a kind of capital (see Section 4.4.2) and the incorporation of the effects of expected capital gains in natural resource stocks arising from the fixity of their supply in the face of continued demand (see Section 4.2).

We face significant challenges in applying the theory empirically. Despite the significant uncertainties, we are able to arrive at empirical estimates that, in our view, provide meaningful insights as to the extent to which various countries have achieved sustainability. Our results imply that the United States, China, and India are, so far, meeting the sustainability criterion. In our estimates, Brazil also meets the requirement, though by a narrow margin. The depletion of Venezuela's natural resources exceeds its investment in human and reproducible capital. In the United States, China, and India, on the other hand, investment in human capital (primarily in the United States and India) and in reproducible capital (primarily in China) significantly outweigh the adverse wealth effects from natural resource depletion and from higher oil prices to these net importers. Our explorations of health capital lead us to the finding that the value of this capital is more than twice as large as all other forms of capital combined. As a result, health capital's growth rate largely determines the growth rate of comprehensive wealth.

We recognize that many limitations remain in our approach. On the theoretical side, the analysis of health capital is an innovation that will require much further study to understand. The results so far suggest that health capital magnitudes and their changes swamp other considerations. It is very likely that this is an important observation, but it has not yet been embodied into a persuasive theoretical framework to clarify its significance. We must therefore consider the results on health capital to be suggestive and an invitation to future research.

Three empirical issues deserve mention as well. First, the validity of the empirical results on sustainability and wealth measurement is constrained by the severe limits of the available data. Measurement of most of the variables comes from surveys and reports of varying degrees of reliability and conceptual consistency. These limits hold even for the quantity variables but even more severely for the shadow prices. Thus, we make human capital depend only on education, though it is well established that they also depend on work experience and on 
conditions of family upbringing. Health capital is measured only by mortality (one of the more reliable figures), but satisfaction from health depends on the length of illnesses and on the degree of comfort and functionality brought about by medical treatment and by changes in the provision of public goods (e.g., accessibility requirements).

Second, the aggregation of various kinds of consumption and capital goods, though common throughout macroeconomic analysis, may give rise to biases of unknown magnitude. These problems may be especially important in measurement of total factor productivity, which plays a significant role in our results.

Third, it should be recognized that the analysis was devoted to the development of productive capacity over time for a given nation. It was not immediately intended to make comparisons among nations, though it is clearly relevant to that purpose. In particular, the comparisons of value of statistical life and therefore health capital per capita across countries cannot be taken to be definitive. 


\section{References}

Arrow, K.J., P. Dasgupta, and K.-G. Mäler (2003), "The Genuine Savings Criterion and the Value of Population", Economic Theory, 21(2), 217-225.

Arrow, K.J., P. Dasgupta, L. Goulder, G. Daily, P.R. Ehrlich, G.M. Heal, S. Levin, K.-G. Mäler, S. Schneider, D.A. Starrett, and B. Walker (2004), "Are We Consuming Too Much?", Journal of Economic Perspectives, 18(1), 147-172.

Arrow, K.J., P. Dasgupta, L.H. Goulder, K. Mumford, and K. Oleson (2007), "China, the U.S., and Sustainability: Perspectives Based on Comprehensive Wealth", Mimeo., Department of Economics, Stanford University.

BP (2005), Statistical Review of World Energy, June 2005, http://www.bp.com/

Becker, G.S., T.J. Philipson, and R.S. Soares (2005), "The Quantity and Quality of Life and the Evolution of World Inequality", American Economic Review, 95(1), 227-291.

Dasgupta, P. (2001), Human Well-Being and the Natural Environment (Oxford University Press, Oxford). 2nd Ed. 2004.

Dasgupta, P. and K.-G. Mäler (2000), Net National Product, Wealth, and Social Well-Being", Environment and Development Economics, 5(1), 69-93.

Food and Agriculture Organization, (2006), “Global Forest Resources Assessment 2005”, United Nations FOA Forestry Paper, 147.

Hamilton, K. (1994), "Green Adjustments to GDP", Resources Policy, 20(3), 155-168.

Hamilton, K. and M. Clemens (1999), "Genuine Savings Rates in Developing Countries", World Bank Economic Review, 13(2), 333-56.

Houghton, R. A. (2005), “Aboveground Forest Biomass and the Global Carbon Balance,” Global Change Biology 11, 945-58.

Jorgenson, Dale W., J. Steven Landfeld, and William D. Nordhaus (2006), eds., A New Architecture for the U.S. National Accounts." National Bureau of Economic Research Studies in Income and Wealth (Chicago: University of Chicago Press).

Klenow, P.J. and A. Rodríguez-Clare (1997), "The Neoclassical Revival in Growth Economics: Has It Gone Too Far?", in B. Bernanke and J. Rotemberg, eds., NBER Macroeconomics Annual 1997 (Cambridge, MA: MIT Press).

Klenow, P.J. and A. Rodríguez-Clare (2005), "Externalities and Growth.” In P. Aghion and S. Durlauf (eds) Handbook of Economic Growth. Amsterdam: North Holland. 
Lane, P. R. and G. M. Milesi-Ferretti (2007), "The External Wealth of Nations Mark II: Revised and Extended Estimates of Foreign Assets and Liabilities, 1970-2004," Journal of International Economics, Elsevier, 73(2), 223-250.

Murphy, K.M., and R.H. Topel (2006), “The Value of Health and Longevity," Journal of Political Economy, 114(5), 871-904.

Nordhaus, W. D. (2002), "The Health of Nations: The Contribution of Improved Health to Living Standards," NBER Working Paper No. 8818.

Nordhaus, W.D. and J. Boyer (2000), Warming the World: Economic Models of Global Warming (Cambridge, MA: MIT Press).

Pearce, D.W. and G. Atkinson (1993), "Capital Theory and the Measurement of Sustainable Development: An Indicator of Weak Sustainability", Ecological Economics, 8, 103-108.

Samuelson, P.A. (1961), "The Evaluation of 'Social Income': Capital Formation and Wealth", in F.A. Lutz and D.C. Hague, eds., The Theory of Capital (London: MacMillan).

Serageldin, I. (1996), Sustainability and the Wealth of Nations: First Steps in an Ongoing Journey, Environmentally Sustainable Development Studies and Monograph Series No. 5 (Washington DC: World Bank).

Serageldin, I. and A. Steer (eds.) (1994), Making Development Sustainable: From Concepts to Action, Environmentally Sustainable Development Studies and Monograph Series No. 2 (Washington DC: World Bank).

Tol, R. S. J. (2009), "The Economic Effects of Climate Change," Journal of Economic Perspectives, 23(2), 29-51.

U.S. Geological Survey (2006), Mineral Commodity Summaries 2006 (Washington, DC: U.S. Government Printing Office).

Viscusi, W. K. and J. E. Aldy (2003), " The Value of a Statistical Life: A Critical Review of Market Estimates throughout the World," Journal of Risk and Uncertainty, 27(1), 5-76.

World Bank (1997), Expanding the Measure of Wealth: Indicators of Environmentally Sustainable Development (Washington, DC: World Bank).

World Bank (2006), Where is the Wealth of Nations? (Washington, DC: World Bank).

World Commission on Environment and Development (1987), Our Common Future (New York: Oxford University Press). 
Table 1: Natural Capital Stocks: Quantities, Prices and Values, 1995-2000

(prices in 2000 US dollars, stock values in 2000 US billions of dollars)

UNITED STATES

\begin{tabular}{|c|c|c|c|c|c|c|c|c|c|c|c|c|c|c|}
\hline & Oil & $\begin{array}{c}\text { Natural } \\
\text { Gas }\end{array}$ & Bauxite & Copper & Iron & Gold & Lead & Nickel & Phosphate & Zinc & Timber & $\begin{array}{c}\text { Forest } \\
\text { Benefits }\end{array}$ & Land & $\begin{array}{l}\text { TOTAL } \\
\text { Natural } \\
\text { Capital }\end{array}$ \\
\hline Capital Stock 1995 & 54.91 & 10.22 & & 0.10 & & & 0.02 & & 4.20 & & 26.105 & 0.300 & & \\
\hline Capital Stock 2000 & 40.28 & 7.50 & & 0.09 & & & 0.02 & & 4.00 & & 26.976 & 0.302 & & \\
\hline Change in Stock & -14.63 & -2.73 & & -0.01 & & & 0.00 & & -0.20 & & 0.871 & 0.002 & & \\
\hline Average Price & 20.21 & 102 & & 2,231 & & & 823 & & 42 & & 129 & & & \\
\hline Extraction Cost & 17.73 & 88 & & 1,513 & & & 634 & & 35 & & 30 & & & \\
\hline Accounting Price & 2.48 & 14.55 & & 718 & & & 189 & & 7 & & 99 & 3,149 & & \\
\hline 1995 Stock Value & 136.15 & 148.69 & & 70.89 & & & 4.23 & & 30.83 & & 2578.18 & 946.05 & 1779.70 & 5694.73 \\
\hline Value of Change & -36.27 & -39.66 & & -6.29 & & & -0.45 & & -1.47 & & 86.07 & 5.74 & & 7.68 \\
\hline
\end{tabular}

\section{CHINA}

\begin{tabular}{|c|c|c|c|c|c|c|c|c|c|c|c|c|c|c|}
\hline & Oil & $\begin{array}{c}\text { Natural } \\
\text { Gas }\end{array}$ & Bauxite & Copper & Iron & Gold & Lead & Nickel & Phosphate & Zinc & Timber & $\begin{array}{c}\text { Forest } \\
\text { Benefits }\end{array}$ & Land & $\begin{array}{l}\text { TOTAL } \\
\text { Natural } \\
\text { Capital }\end{array}$ \\
\hline Capital Stock 1995 & 27.88 & 2.48 & 2.04 & 0.04 & 15.39 & 0.00 & 0.03 & 0.01 & & & 11.753 & 0.167 & & \\
\hline Capital Stock 2000 & 22.02 & 2.37 & 2.00 & 0.04 & 15.00 & 0.00 & 0.03 & 0.01 & & & 12.450 & 0.177 & & \\
\hline Change in Stock & -5.87 & -0.12 & -0.04 & 0.00 & -0.39 & 0.00 & 0.00 & 0.00 & & & 0.698 & 0.010 & & \\
\hline Average Price & 20.21 & 102 & 25 & 2,231 & 46 & $10.9 \mathrm{~m}$ & 823 & 7,394 & & & 61 & & & \\
\hline Extraction Cost & 14.18 & 44 & 17 & 989 & 10 & $10.7 \mathrm{~m}$ & 696 & 7,038 & & & 19 & & & \\
\hline Accounting Price & 6.03 & 58.28 & 8 & 1,242 & 35 & $.207 \mathrm{~m}$ & 126 & 356 & & & 42 & 2,432 & & \\
\hline 1995 Stock Value & 168.02 & 144.67 & 16.64 & 49.08 & 545.9 & 1.03 & 4.19 & 2.90 & & & 487.97 & 406.31 & 2027.81 & 3854.52 \\
\hline alue of Change & -35.36 & -6.76 & -0.32 & -3.14 & -13.77 & -0.18 & -0.40 & -0.09 & & & 28.96 & 24.15 & & -6.90 \\
\hline
\end{tabular}




\begin{tabular}{|c|c|c|c|c|c|c|c|c|c|c|c|c|c|c|}
\hline & Oil & $\begin{array}{c}\text { Natural } \\
\text { Gas }\end{array}$ & Bauxite & Copper & Iron & Gold & Lead & Nickel & Phosphate & Zinc & Timber & $\begin{array}{c}\text { Forest } \\
\text { Benefits }\end{array}$ & Land & $\begin{array}{c}\text { TOTAL } \\
\text { Natural } \\
\text { Capital }\end{array}$ \\
\hline Capital Stock 1995 & 15.27 & 0.31 & 4.96 & 0.01 & 11.61 & & & & & 0.01 & 15.718 & 0.405 & & \\
\hline Capital Stock 2000 & 13.41 & 0.28 & 4.90 & 0.01 & 11.00 & & & & & 0.01 & 15.224 & 0.395 & & $2,619.42$ \\
\hline Change in Stock & -1.86 & -0.03 & -0.06 & 0.00 & -0.61 & & & & & 0.00 & -0.494 & -0.011 & & \\
\hline Average Price & 20.21 & 102 & 25 & 2,231 & 46 & & & & & 1,205 & 43 & & & \\
\hline Extraction Cost & 17.69 & 44 & 18 & 989 & 8 & & & & & 1,002 & 18 & & & \\
\hline Accounting Price & 2.52 & 58.28 & 7 & 1,242 & 38 & & & & & 203 & 25 & 2,432 & & \\
\hline 1995 Stock Value & 38.45 & 18.34 & 35.66 & 14.92 & 441.8 & & & & & 1.17 & 397.99 & 985.67 & 754.39 & 2688.40 \\
\hline Value of Change & -4.67 & -1.85 & -0.42 & -0.23 & -23.12 & & & & & -0.11 & -12.50 & -26.08 & & -68.98 \\
\hline
\end{tabular}

INDIA

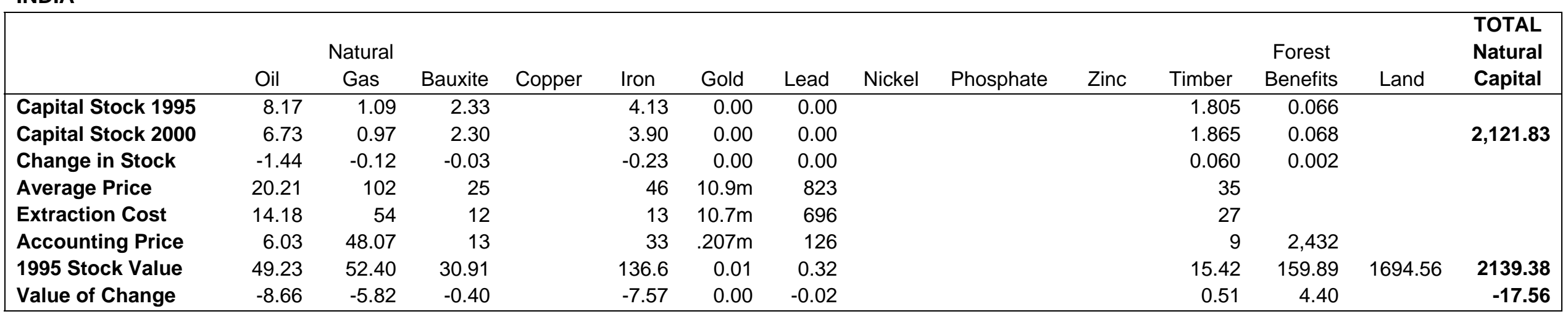

VENEZUELA

\begin{tabular}{|c|c|c|c|c|c|c|c|c|c|c|c|c|c|c|}
\hline & Oil & $\begin{array}{c}\text { Natural } \\
\text { Gas }\end{array}$ & Bauxite & Copper & Iron & Gold & Lead & Nickel & Phosphate & Zinc & Timber & $\begin{array}{c}\text { Forest } \\
\text { Benefits }\end{array}$ & Land & $\begin{array}{l}\text { TOTAL } \\
\text { Natural } \\
\text { Capital }\end{array}$ \\
\hline Capital Stock 1995 & 87.67 & 4.48 & 0.37 & & 3.60 & & & 0.61 & & & 3.30 & 0.04 & & \\
\hline Capital Stock 2000 & 81.63 & 4.33 & 0.35 & & 3.55 & & & 0.61 & & & 3.21 & 0.04 & & $3,591.29$ \\
\hline Change in Stock & -6.04 & -0.15 & -0.02 & & -0.06 & & & 0.00 & & & -0.09 & 0.00 & & \\
\hline Average Price & 20.21 & 102 & 25 & & 46 & & & 7,394 & & & 60 & & & \\
\hline Extraction Cost & 4.34 & 37 & 18 & & 17 & & & 4,747 & & & 27 & & & \\
\hline Accounting Price & 15.87 & 65.03 & 7 & & 29 & & & 2,647 & & & 33 & 2,432 & & \\
\hline 1995 Stock Value & $1,391.1$ & 291.21 & 2.68 & & 103.2 & & & 1614 & & & 108.23 & 98.42 & 94.84 & 3704.42 \\
\hline Value of Change & -95.87 & -9.63 & -0.17 & & -1.58 & & & -0.01 & & & -3.08 & -2.80 & & -113.13 \\
\hline
\end{tabular}


Table 2: Components of Comprehensive Investment

UNITED STATES

(in billions of 2000 US dollars)

\begin{tabular}{|c|c|c|c|c|c|c|}
\hline & $\begin{array}{l}\text { Natural } \\
\text { Capital }\end{array}$ & $\begin{array}{l}\text { Human } \\
\text { Capital }\end{array}$ & $\begin{array}{l}\text { Reproducible } \\
\text { Capital }\end{array}$ & $\begin{array}{c}\text { Oil Net } \\
\text { Capital Gains }\end{array}$ & $\begin{array}{l}\text { Carbon } \\
\text { Damages }\end{array}$ & TOTAL \\
\hline 1995 Capital Stock & $5,694.73$ & $60,086.93$ & $13,430.66$ & & & $79,212.320$ \\
\hline 2000 Capital Stock & $5,702.41$ & $64,802.68$ & $15,923.83$ & & & $84,889.968$ \\
\hline Change 1995-2000 & 7.68 & $4,715.75$ & $2,493.17$ & $-1,367.38$ & -171.572 & $5,677.648$ \\
\hline Percentage Change & $0.13 \%$ & $7.85 \%$ & $18.56 \%$ & & & $7.17 \%$ \\
\hline Growth Rate & $0.03 \%$ & $1.52 \%$ & $3.46 \%$ & & & $1.39 \%$ \\
\hline
\end{tabular}

CHINA

\begin{tabular}{|lrrrrrr|}
\hline & $\begin{array}{l}\text { Natural } \\
\text { Capital }\end{array}$ & $\begin{array}{l}\text { Human } \\
\text { Capital }\end{array}$ & $\begin{array}{c}\text { Reproducible } \\
\text { Capital }\end{array}$ & $\begin{array}{c}\text { Oil Net } \\
\text { Capital Gains }\end{array}$ & $\begin{array}{c}\text { Carbon } \\
\text { Damages }\end{array}$ & \multicolumn{1}{c|}{ TOTAL } \\
\cline { 2 - 6 } 1995 Capital Stock & $3,854.52$ & $8,492.93$ & $3,706.23$ & & & $\mathbf{1 6 , 0 5 3 . 6 8 0}$ \\
2000 Capital Stock & $3,847.62$ & $9,394.69$ & $6,471.69$ & & $\mathbf{1 9 , 3 9 8 . 9 1 6}$ \\
Change 1995-2000 & -6.90 & 901.76 & $2,765.46$ & -305.80 & -9.284 & $\mathbf{3 , 3 4 5 . 2 3 6}$ \\
Percentage Change & $-0.18 \%$ & $10.62 \%$ & $74.62 \%$ & & $\mathbf{2 0 . 8 4 \%}$ \\
Growth Rate & $-0.04 \%$ & $2.04 \%$ & $11.79 \%$ & & $\mathbf{3 . 8 6 \%}$ \\
\hline
\end{tabular}

BRAZIL

\begin{tabular}{|lrrrrrr|}
\hline & $\begin{array}{l}\text { Natural } \\
\text { Capital }\end{array}$ & $\begin{array}{l}\text { Human } \\
\text { Capital }\end{array}$ & $\begin{array}{c}\text { Reproducible } \\
\text { Capital }\end{array}$ & $\begin{array}{c}\text { Oil Net } \\
\text { Capital Gains }\end{array}$ & $\begin{array}{c}\text { Carbon } \\
\text { Damages }\end{array}$ & \multicolumn{1}{c|}{ TOTAL } \\
\cline { 2 - 6 } 1995 Capital Stock & $2,688.40$ & $7,157.81$ & $1,728.80$ & & & $\mathbf{1 1 , 5 7 5 . 0 1 0}$ \\
2000 Capital Stock & $2,619.42$ & $8,248.34$ & $1,756.91$ & & $\mathbf{1 2 , 4 6 3 . 0 9 4}$ \\
Change 1995-2000 & -68.98 & $1,090.53$ & 28.11 & -119.05 & -42.526 & $\mathbf{8 8 8 . 0 8 4}$ \\
Percentage Change & $-2.57 \%$ & $15.24 \%$ & $1.63 \%$ & & $\mathbf{7 . 6 7 \%}$ \\
Growth Rate & $-0.52 \%$ & $2.88 \%$ & $0.32 \%$ & & $\mathbf{1 . 4 9 \%}$ \\
\hline
\end{tabular}

INDIA

\begin{tabular}{|lrrrrrr|}
\hline & $\begin{array}{l}\text { Natural } \\
\text { Capital }\end{array}$ & $\begin{array}{l}\text { Human } \\
\text { Capital }\end{array}$ & $\begin{array}{c}\text { Reproducible } \\
\text { Capital }\end{array}$ & $\begin{array}{c}\text { Oil Net } \\
\text { Capital Gains }\end{array}$ & $\begin{array}{c}\text { Carbon } \\
\text { Damages }\end{array}$ & \multicolumn{1}{c|}{ TOTAL } \\
\cline { 2 - 6 } Capital Stock & $2,139.38$ & $5,983.36$ & $1,429.82$ & & & $\mathbf{9 , 5 5 2 . 5 6 0}$ \\
Co00 Capital Stock & $2,121.83$ & $6,934.61$ & $2,035.00$ & & & $\mathbf{1 0 , 8 6 1 . 8 9 8}$ \\
Change 1995-2000 & -17.56 & 951.25 & 605.18 & -141.50 & -88.042 & $\mathbf{1 , 3 0 9 . 3 3 8}$ \\
Percentage Change & $-0.82 \%$ & $15.90 \%$ & $42.33 \%$ & & $\mathbf{1 3 . 7 1 \%}$ \\
Growth Rate & $-0.16 \%$ & $2.99 \%$ & $7.31 \%$ & & $\mathbf{2 . 6 0 \%}$ \\
\hline
\end{tabular}

VENEZUELA

\begin{tabular}{|lrrrrrr|}
\hline & $\begin{array}{c}\text { Natural } \\
\text { Capital }\end{array}$ & $\begin{array}{c}\text { Human } \\
\text { Capital }\end{array}$ & $\begin{array}{c}\text { Reproducible } \\
\text { Capital }\end{array}$ & $\begin{array}{c}\text { Oil Net } \\
\text { Capital Gains }\end{array}$ & $\begin{array}{c}\text { Carbon } \\
\text { Damages }\end{array}$ & \multicolumn{1}{c|}{ TOTAL } \\
\cline { 2 - 6 } 1995 Capital Stock & $3,704.417$ & 526.61 & 201.21 & & & $\mathbf{4 , 4 3 2 . 2 3 7}$ \\
2000 Capital Stock & $3,591.29$ & 587.62 & 204.71 & & & $\mathbf{4 , 3 8 3 . 6 1 5}$ \\
Change 1995-2000 & -113.131 & 61.01 & 3.51 & 322.04 & -11.552 & $\mathbf{2 6 1 . 8 6 6}$ \\
Percentage Change & $-3.05 \%$ & $11.59 \%$ & $1.74 \%$ & & & $\mathbf{5 . 9 1 \%}$ \\
Growth Rate & $-0.62 \%$ & $2.22 \%$ & $0.35 \%$ & & $\mathbf{1 . 1 5 \%}$ \\
\hline
\end{tabular}


Table 3: Growth Rates (in Percent) of Per-Capita Comprehensive Wealth, Adjusted for Technological Change

\begin{tabular}{|c|c|c|c|c|c|c|}
\hline & $\begin{array}{c}(1) \\
\text { Comprehensive } \\
\text { Wealth Growth } \\
\text { Rate }\end{array}$ & $\begin{array}{c}\text { (2) } \\
\text { Population } \\
\text { Growth } \\
\text { Rate }\end{array}$ & $\begin{array}{c}\text { (3) } \\
\text { Per Capita } \\
\text { Comprehensive } \\
\text { Wealth Growth } \\
\text { Rate, Accounting } \\
\text { for Population } \\
\text { Growth } \\
\text { [(1) - (2)] }\end{array}$ & $\begin{array}{c}\text { (4) } \\
\text { TFP } \\
\text { Growth } \\
\text { Rate }\end{array}$ & $\begin{array}{c}\text { (5) } \\
\text { Per Capita } \\
\text { Comprehensive } \\
\text { Wealth Growth } \\
\text { Rate, } \\
\text { Accounting for } \\
\text { TFP Growth } \\
\text { [(3)+ (4)] }\end{array}$ & $\begin{array}{c}\text { (6) } \\
\text { Per } \\
\text { Capita } \\
\text { GDP } \\
\text { Growth } \\
\text { Rate }\end{array}$ \\
\hline US & 1.39 & 1.17 & 0.22 & 1.48 & 1.70 & 2.93 \\
\hline CHINA & 3.86 & 0.94 & 2.92 & 2.71 & 5.63 & 7.60 \\
\hline BRAZIL & 1.49 & 1.50 & -0.01 & 0.15 & 0.14 & 0.50 \\
\hline INDIA & 2.60 & 1.74 & 0.86 & 1.84 & 2.70 & 3.99 \\
\hline VENEZUELA & 1.15 & 1.98 & -0.79 & -2.12 & -2.94 & -1.20 \\
\hline
\end{tabular}

Table 4: Per Capita Health Capital and Valuation

\begin{tabular}{|lrrrrr|}
\hline & United States & China & Brazil & India & Venezuela \\
\cline { 2 - 6 } & & & & & \\
Per-Capita Health Capital & & & & & \\
2000 & 16.067 & 16.408 & 16.513 & 16.165 & 17.131 \\
2005 & 16.212 & 16.495 & 16.738 & 16.285 & 17.235 \\
Change & 0.145 & 0.087 & 0.225 & 0.121 & 0.104 \\
Percentage change & $0.90 \%$ & $0.53 \%$ & $1.36 \%$ & $0.75 \%$ & $0.61 \%$ \\
& & & & & \\
VSLY & $\$ 392,109$ & $\$ 104,268$ & $\$ 148,187$ & $\$ 77,904$ & $\$ 125,402$ \\
VSL & & & & \\
2000 & & & & & \\
2005 & $\$ 6,300,000$ & $\$ 1,710,857$ & $\$ 2,447,023$ & $\$ 1,259,319$ & $\$ 2,148,269$ \\
Change & $\$ 6,356,761$ & $\$ 1,719,892$ & $\$ 2,480,400$ & $\$ 1,268,710$ & $\$ 2,161,281$ \\
& $\$ 56,761$ & $\$ 9,035$ & $\$ 33,377$ & $\$ 9,391$ & $\$ 13,012$ \\
\hline
\end{tabular}


Table 5: Per Capita Components of Comprehensive Investment Including Health (in 2000 US dollars)

UNITED STATES (per capita)

\begin{tabular}{|c|c|c|c|c|c|c|c|}
\hline & $\begin{array}{l}\text { Natural } \\
\text { Capital }\end{array}$ & $\begin{array}{l}\text { Human } \\
\text { Capital }\end{array}$ & $\begin{array}{c}\text { Reproducible } \\
\text { Capital }\end{array}$ & $\begin{array}{l}\text { Health } \\
\text { Capital }\end{array}$ & $\begin{array}{c}\text { Oil Net } \\
\text { Capital Gains }\end{array}$ & $\begin{array}{c}\text { Carbon } \\
\text { Damages }\end{array}$ & TOTAL \\
\hline 1995 Capital Stock & $\$ 21,386$ & $\$ 225,655$ & $\$ 50,438$ & $\$ 6,300,000$ & & & $\$ 6,597,480$ \\
\hline 2000 Capital Stock & $\$ 20,205$ & $\$ 229,614$ & $\$ 56,423$ & $\$ 6,356,761$ & & & $\$ 6,657,550$ \\
\hline Change 1995-2000 & $-\$ 1,181$ & $\$ 3,959$ & $\$ 5,984$ & $\$ 56,761$ & $-\$ 4,845$ & $-\$ 608$ & $\$ 60,071$ \\
\hline Percentage Change & $-5.52 \%$ & $1.75 \%$ & $11.86 \%$ & $0.90 \%$ & & & $0.91 \%$ \\
\hline Growth Rate & $-1.13 \%$ & $0.35 \%$ & $2.27 \%$ & $0.18 \%$ & & & $0.18 \%$ \\
\hline
\end{tabular}

CHINA (per capita)

\begin{tabular}{|c|c|c|c|c|c|c|c|}
\hline & $\begin{array}{l}\text { Natural } \\
\text { Capital }\end{array}$ & $\begin{array}{l}\text { Human } \\
\text { Capital }\end{array}$ & $\begin{array}{c}\text { Reproducible } \\
\text { Capital }\end{array}$ & $\begin{array}{l}\text { Health } \\
\text { Capital }\end{array}$ & $\begin{array}{c}\text { Oil Net } \\
\text { Capital Gains }\end{array}$ & $\begin{array}{c}\text { Carbon } \\
\text { Damages }\end{array}$ & TOTAL \\
\hline 1995 Capital Stock & $\$ 3,199$ & $\$ 7,049$ & $\$ 3,076$ & $\$ 1,710,857$ & & & $\$ 1,724,181$ \\
\hline 2000 Capital Stock & $\$ 3,047$ & $\$ 7,440$ & $\$ 5,126$ & $\$ 1,719,892$ & & & $\$ 1,735,256$ \\
\hline Change 1995-2000 & $-\$ 152$ & $\$ 392$ & $\$ 2,049$ & $\$ 9,035$ & $-\$ 242$ & $-\$ 7$ & $\$ 11,075$ \\
\hline Percentage Change & $-4.75 \%$ & $5.55 \%$ & $66.62 \%$ & $0.53 \%$ & & & $0.64 \%$ \\
\hline Growth Rate & $-0.97 \%$ & $1.09 \%$ & $10.75 \%$ & $0.11 \%$ & & & $0.13 \%$ \\
\hline
\end{tabular}

BRAZIL (per capita)

\begin{tabular}{|c|c|c|c|c|c|c|c|}
\hline & $\begin{array}{l}\text { Natural } \\
\text { Capital }\end{array}$ & $\begin{array}{l}\text { Human } \\
\text { Capital }\end{array}$ & $\begin{array}{c}\text { Reproducible } \\
\text { Capital }\end{array}$ & $\begin{array}{l}\text { Health } \\
\text { Capital }\end{array}$ & $\begin{array}{c}\text { Oil Net } \\
\text { Capital Gains }\end{array}$ & $\begin{array}{c}\text { Carbon } \\
\text { Damages }\end{array}$ & TOTAL \\
\hline 1995 Capital Stock & $\$ 16,659$ & $\$ 44,355$ & $\$ 10,713$ & $\$ 2,447,023$ & & & $\$ 2,518,750$ \\
\hline 2000 Capital Stock & $\$ 15,066$ & $\$ 47,443$ & $\$ 10,105$ & $\$ 2,480,400$ & & & $\$ 2,552,086$ \\
\hline Change 1995-2000 & $-\$ 1,593$ & $\$ 3,088$ & $-\$ 607$ & $\$ 33,377$ & $-\$ 685$ & $-\$ 245$ & $\$ 33,336$ \\
\hline Percentage Change & $-9.56 \%$ & $6.96 \%$ & $-5.67 \%$ & $1.36 \%$ & & & $1.32 \%$ \\
\hline Growth Rate & $-1.99 \%$ & $1.36 \%$ & $-1.16 \%$ & $0.27 \%$ & & & $0.26 \%$ \\
\hline
\end{tabular}

INDIA (per capita)

\begin{tabular}{|c|c|c|c|c|c|c|c|}
\hline & $\begin{array}{l}\text { Natural } \\
\text { Capital }\end{array}$ & $\begin{array}{l}\text { Human } \\
\text { Capital }\end{array}$ & $\begin{array}{l}\text { Reproducible } \\
\text { Capital }\end{array}$ & $\begin{array}{l}\text { Health } \\
\text { Capital }\end{array}$ & $\begin{array}{c}\text { Oil Net } \\
\text { Capital Gains }\end{array}$ & $\begin{array}{c}\text { Carbon } \\
\text { Damages }\end{array}$ & TOTAL \\
\hline 1995 Capital Stock & $\$ 2,295$ & $\$ 6,419$ & $\$ 1,534$ & $\$ 1,259,319$ & & & $\$ 1,269,567$ \\
\hline 2000 Capital Stock & $\$ 2,276$ & $\$ 7,439$ & $\$ 2,183$ & $\$ 1,268,710$ & & & $\$ 1,280,382$ \\
\hline Change 1995-2000 & $-\$ 19$ & $\$ 1,020$ & $\$ 649$ & $\$ 9,391$ & $-\$ 139$ & $-\$ 87$ & $\$ 10,816$ \\
\hline Percentage Change & $-0.82 \%$ & $15.90 \%$ & $42.33 \%$ & $0.75 \%$ & & & $0.85 \%$ \\
\hline Growth Rate & $-0.16 \%$ & $2.99 \%$ & $7.31 \%$ & $0.15 \%$ & & & $0.17 \%$ \\
\hline
\end{tabular}

VENEZUELA (per capita)

\begin{tabular}{|c|c|c|c|c|c|c|c|}
\hline & $\begin{array}{l}\text { Natural } \\
\text { Capital }\end{array}$ & $\begin{array}{l}\text { Human } \\
\text { Capital }\end{array}$ & $\begin{array}{l}\text { Reproducible } \\
\text { Capital }\end{array}$ & $\begin{array}{l}\text { Health } \\
\text { Capital }\end{array}$ & $\begin{array}{c}\text { Oil Net } \\
\text { Capital Gains }\end{array}$ & $\begin{array}{c}\text { Carbon } \\
\text { Damages }\end{array}$ & TOTAL \\
\hline 1995 Capital Stock & $\$ 163,589$ & $\$ 23,890$ & $\$ 9,128$ & $\$ 2,148,269$ & & & $\$ 2,344,876$ \\
\hline 2000 Capital Stock & $\$ 143,789$ & $\$ 24,171$ & $\$ 8,420$ & $\$ 2,161,281$ & & & $\$ 2,350,433$ \\
\hline Change $1995-2000$ & $-\$ 19,800$ & $\$ 281$ & $-\$ 708$ & $\$ 13,012$ & $\$ 13,247$ & $-\$ 475$ & $\$ 5,557$ \\
\hline Percentage Change & $-12.10 \%$ & $1.18 \%$ & $-7.75 \%$ & $0.61 \%$ & & & $0.24 \%$ \\
\hline Growth Rate & $-2.55 \%$ & $0.23 \%$ & $-1.60 \%$ & $0.12 \%$ & & & $0.05 \%$ \\
\hline
\end{tabular}


Table 6: Sensitivity Analysis

Growth Rates (in percent) of Per-Capita Comprehensive Wealth under Alternative Assumptions

A: Social Cost of Carbon

\begin{tabular}{|lccccc|}
\hline & United States & China & Brazil & India & Venezuela \\
\cline { 2 - 6 } & & & & & \\
\$50/ton cost of carbon & 1.70 & 5.63 & 0.14 & 2.70 & -2.91 \\
\$100/ton cost of carbon & 1.66 & 5.62 & 0.07 & 2.54 & -2.96 \\
\$500/ton cost of carbon & 1.33 & 5.54 & -0.49 & 1.16 & -3.37 \\
\hline
\end{tabular}

Per-capita comprehensive wealth growth rates include technological change but exclude health

B: Inclusion / Exclusion of Health Capital

\begin{tabular}{|lccccc|}
\hline & United States & China & Brazil & India & Venezuela \\
\cline { 2 - 6 } & & & & & \\
Health Capital Excluded & & & & & \\
No TFP Adjustment & 0.22 & 2.92 & -0.01 & 0.86 & -0.79 \\
TFP Adjustment & 1.70 & 5.63 & 0.14 & 2.70 & -2.94 \\
& & & & & \\
Health Capital Included & & & & & \\
No TFP Adjustment & 0.18 & 0.13 & 0.26 & 0.17 & -05 \\
TFP Adjustment & 1.66 & 2.84 & 0.41 & 2.01 & -2.07 \\
\hline
\end{tabular}

C: Discount Rate Applied to Additional Years of Life

\begin{tabular}{|lccccc|}
\hline & United States & China & Brazil & India & Venezuela \\
\cline { 2 - 6 } & & & & & \\
Low discounting (0.03) & 1.72 & 2.88 & 0.53 & 2.06 & -2.01 \\
Base Case (0.05) & 1.66 & 2.84 & 0.41 & 2.01 & -2.07 \\
High discounting (0.07) & 1.62 & 2.81 & 0.34 & 1.98 & -2.11 \\
\hline
\end{tabular}

Per-capita comprehensive wealth growth rates in this panel include technological change and health

\section{D: Value of a Statistical Life}

\begin{tabular}{|c|c|c|c|c|c|}
\hline & United States & China & Brazil & India & Venezuela \\
\hline $\begin{array}{l}\text { VSL proportional to the } \\
0.6 \text { power of GDP }\end{array}$ & 1.66 & 2.84 & 0.41 & 2.01 & -2.07 \\
\hline VSL proportional to GDP & 1.66 & 2.87 & 0.40 & 2.03 & -2.14 \\
\hline $\begin{array}{l}\text { VSL the same for all } \\
\text { countries ( } \$ 6.3 \text { million) }\end{array}$ & 1.66 & 2.82 & 0.42 & 1.99 & -2.03 \\
\hline $\begin{array}{l}\text { VSL the same for all } \\
\text { countries ( } \$ 1.0 \text { million) }\end{array}$ & 1.67 & 2.85 & 0.40 & 2.02 & -2.14 \\
\hline
\end{tabular}

Per-capita comprehensive wealth growth rates in this panel include technological change and health 